\title{
IbM KELOMPOK TANI TANAMAN CABE DI DESA BATU KABUPATEN MINAHASA UTARA
}

\author{
Sukmarayu P. Gedoan \& Utari Satiman \\ Jurusan Biologi, Fakultas Matematika dan Ilmu Pengetahuan Alam, Universitas Negeri Manado (UNIMA) \\ sgedoan@gmail.com
}

\begin{abstract}
Abstrak
Desa Batu merupakan bagian dari kecamatan Likupang kabupaten Minahasa Utara. Keterbatasan pengetahuan petani terhadap masalah pertanian menjadi rentetan masalah yang tidak pernah selesai. Petani di desa Batu tidak mempunyai perencanaan yang tepat dalam mengelola pertaniannya sendiri sehingga komoditi pertanian yang ditanam tidak mempunyai nilai tambah dalam meningkatkan perekonomian keluarga. Solusi yang akan dilakukan adalah untuk menjawab permasalahan tersebut di atas yaitu: (1) meningkatkan produktivitas tanaman cabe, kualitas buah cabe. Langkah yang dilakukan untuk mengatasi masalah tersebut di atas adalah memberikan pengetahuan dalam budidaya tanaman cabe yang baik dan benar. Secara spesifik program ini mencakup kegiatan budidaya tanaman cabe, pasca panen cabe, dan pembuatan produk olahan cabe. Sosialisasi program pada kelompok tani di desa Batu Likupang Selatan dapat berjalan dengan baik. Pemahaman yang meningkat dari petani mitra dalam budidaya tanaman cabai berupa praktik penanaman, pemeliharaan, dan pengendalian hama.

Kata Kunci: Tanaman Cabe, Desa Batu, dan Minahasa Utara.
\end{abstract}

\section{PENDAHULUAN}

Dalam rencana pembangunan jangka menengah daerah provinsi Sulawesi Utara 2016-2021 terdapat pembagian atau zonasi penggunaan lahan. Kawasan peruntukan pertanian meliputi seluruh kabupaten dan kota yang memiliki lahan berpotensi untuk pengembangan budidaya tanaman pangan. Desa Batu memiliki potensi yang besar untuk dikembangkan sebagai desa kawasan pertumbuhan pertanian. Desa ini memiliki tingkat kesuburan yang tinggi karena tanahnya termasuk bagian dari tanah vulkanik. Ditinjau dari zona agroklimat Oldeman kabupaten Minahasa Utara termasuk dalam zona A1 yaitu dengan jumlah bulan basah berturut-turut lebih dari sembilan bulan dan jumlah bulan kering kurang dari dua bulan dalam setahun.

Potensi yang besar masih kurang dimanfaatkan oleh masyarakat desa Batu dalam mengembangkan ekonomi rakyat. Masyarakat Batu kadang-kadang merasa menderita kalau harga komoditi harga cabe yang melambung tinggi terutama pada momen tertentu seperti bulan Desember. Penyuluhaan pertanian jarang dilakukan karena keterbatasan petugas penyuluh pertanian lapangan (PPL). Pendekatan yang dilakukan oleh petugas PPL sering tidak menyentuh subtansi permasalahan petani seperti petani membutuhkan penyuluhan tentang tanaman cabe tetapi tidak secara intensif dan masif.

Keterbatasan pengetahuan petani terhadap masalah pertanian menjadi rentetan masalah yang tidak pernah selesai. Petani di desa Batu tidak mempunyai perencanaan yang tepat dalam mengelola pertaniannya sendiri sehingga komoditi pertanian yang ditanam tidak mempunyai nilai tambah dalam meningkatkan 
perekonomian keluarga. Tantangan terbesar yang dihadapi petani yang ada di desa Batu adalah ketidak pastian pendapatan dalam bercocok tanam komoditi pertanian. Petani umumnya bersikap pragmatis dalam menjalankan roda kehidupan mereka menyebabkan pendapatan yang tidak menentu. Keadaan yang memprihatinkan ini menjadi fenomena yang sangat memilukan untuk tetap dipertahankan terjadi. Ketidaktertarikan dalam mengelola tanaman sayuran dengan hanya mengandalkan tanaman tahunan seperti kelapa dan cengkeh menyebabkan ketidakpastian kesejahteraan.

Selain itu pengetahuan petani terhadap pengelolaan tanaman cabe sangat terbatas. Kebiasaan petani yang ada di desa Batu dan umumnya di Minahasa Utara adalah hanya mengandalkan alam dalam memberi hasil dari yang ditanam. Setelah mereka menanam cabe, dibiarkan tumbuh dan tinggal menunggu waktu panen.

Pola pikir seperti pada lagu dengan syair bahwa: "orang bilang tanah kita adalah tanah surga, tongkat, kayu, dan batu jadi tanaman". Pola pikir seperti ini masih kental dianut oleh warga desa Batu khususnya dan Likupang pada umumnya. Oleh sebab itu diperlukan perubahan paradigma berpikir masyarakat bahwa produktivitas suatu tanaman sangat ditentukan oleh masukan berupa pengelolaan tanaman yang benar.

Berdasarkan permasalahan tentang budidaya tanaman cabe petani akan 64 mendapatkan pengetahuan yang sangat penting untuk meningkatkan produktivitas hasil tanamannya. Petani mendapat bekal pengetahuan yang cukup untuk mendapatkan hasil panen yang banyak, mengelola pola tanam yang baik, dan penganganan pasca panen buah cabe.

\section{METODE PELAKSANAAN}

\section{Gambaran Metode Pendekatan}

Dalam pelaksanaan kegiatan IbM ini direncanakan di samping warga belajar yang tergabung dalam kelompok petani "Batu Raja" juga akan melibatkan warga belajar atau khalayak sasaran lainnya yaitu anggota masyarakat dengan kriteria; dari keluarga petani dan kurang memiliki pengetahuan dalam budidaya tanaman cabe, berbudi pekerti yang baik, memiliki daya juang yang tinggi/rajin, dapat berpartisipasi secara aktif dan mempunyai kemauan serta motivasi yang kuat bekerja secara bersama-sama untuk ikut dalam pelaksanaan kegiatan ini serta bersedia dihimpun dalam wadah kelompok usaha tani cabe atau membentuk kelompok petani yang baru. Kegiatan ini diharapkan akan memberikan dampak yang lebih luas terutama dalam mengatasi permasalahan yang dihadapi petani saat ini. Di samping itu dilibatkan juga tokoh masyarakat (adat dan agama) karena dianggap memiliki pengaruh kuat dan menjadi panutan dalam pelaksanaan kegiatan tersebut.

Konkritnya telah disepakati pula bahwa langkah yang akan dilakukan untuk 
mengatasi masalah tersebut di atas adalah memberikan pengetahuan dalam budidaya tanaman cabe yang baik dan benar. Secara spesifik program ini mencakup kegiatan budidaya tanaman cabe. Rangkaian kegiatan tersebut dapat dilakukan secara terintegrasi melalui persiapan lahan. Pengolahan tanah dilakukan secara sempurna dengan mencangkul untuk membersihkan lahan dari kotoran akar bekas tanaman lama dan segala macam gulma yang tumbuh. Hal tersebut dilakukan agar pertumbuhan akar tanaman cabai tidak terganggu dan untuk menghilangkan tumbuhan yang menjadi inang hama dan penyakit. Selanjutnya lahan dicangkul dan digaru dengan manual. Pengcangkulan dan penggaruan bertujuan untuk menggemburkan, memperbaiki aerasi tanah dan untuk menghilangkan organisme penggangu tanaman (OPT) yang bersembunyi di tanah.

Selanjutnya untuk mengatasi permasalahan yang dihadapi oleh kelompok petani mitra dan masyarakat petani lainnya, maka metode pendekatan yang akan diterapkan adalah menggunakan metode "tepat guna" aplikasi ilmu pengetahuan dan teknologi sesuai kebutuhan kelompok mitra dengan pendekatan Andragogik dan partisipatif. Secara komprehensif, dimana permasalahan secara mendasar dibahas dan dipahami bersama dan merupakan buah pemikiran dan justifikasi atau kesepakatan bersama antara pelaksana $\mathrm{I}_{b} \mathrm{M}$ dengan kelompok mitra serta secara bersama-sama dalam menindaklanjutinya melalui proses perencanaan dan implementasi teknologi sesuai kebutuhan mitra. Oleh karena itu sebelum mengimplimentascabe $\mathrm{I}_{\mathrm{b}} \mathrm{M}$ maka perlu penyamaan persepsi dan langkahlangkah solusi dalam mengatasi persoalan yang akan diatasi dan telah disepakati bersama yang kemudian ditawarkan dalam usulan ini. Secara umum gambaran tahapan metode dan pendekatan yang akan dilakukan dalam kegiatan $\mathrm{I}_{b} \mathrm{M}$ ini adalah sebagai berikut.

\section{Sosialisasi Program}

Sosialisasi merupakan salah satu tahapan penting dalam mengenalkan teknologi yang akan diterapkan pada kelompok usaha. Kegiatan tersebut menyangkut transformasi gambaran ilmu pengetahuan dan teknologi dalam upaya memecahkan masalah yang dihadapi oleh petani. Dalam kegiatan sosialisasi ini akan dijelaskan tentang teknologi yang akan disosialisasi yaitu budidaya tanaman cabe seperti persiapan lahan, penanaman, dan pemeliharaan. Dalam sosialisasi dijelaskan pentingnya melakukan budidaya tanaman dengan memberikan mulsa berupa plastik. Penanganan pasca panen merupakan aspek yang perlu mendapat perhatian sehingga penjelasan tentang hal ini sangat diperlukan.

Banyak kelemahan yang sering dijumpai dalam pelaksanaan kegiatan yaitu rendahnya pemahaman program yang akan dilaksanakan. Umumnya petani memahami bahwa program ini adalah bagi-bagi uang sehingga mereka tidak dengan serius 
melakukan program ini. Pemahaman kelompok tani perlu dilakukan untuk meningkatkan rasa tanggung jawab bahwa kegiatan ini penting diikuti dengan serius. Rasa memiliki dapat ditanamkan antara lain melalui pendekatan partisipatif, dimana masyarakat atau anggota kelompok dapat memberi diri sepenuhnya untuk berpartisipasi secara aktif melalui kegiatan bekerja bersama atau aktif dalam proses implementasi kegiatan. Hal tersebut sangat diperlukan mengingat faktor tersebut memberi andil besar terhadap kegagalan berbagai program. Setelah sosialisasi, akan ditindaklanjuti dengan kegiatan proses belajar mengajar dan kegiatan praktek atau implementasi ilmu pengetahuan dan teknologi terhadap warga belajar dan ditindaklanjuti kegiatan proses produksi oleh warga belajar yang dituntun langsung oleh tim pelaksana IbM.

\section{Proses Kegiatan Pembelajaran}

Proses pembelajaran yang dimaksud disini adalah pemberian materi secara teoritis dan tuntunan praktek atau pedoman kerja yang dirangkum dalam suatu buku pedoman kegiatan untuk program pembelajaran dalam rangka memberi kemampuan dan kecakapan terutama keterampilan budidaya tanaman. Aspek lain dalam program pembelajaran adalah menyangkut pemberian pengetahuan dan pembinaan mental kewirausahaan Untuk pencapaian tujuan secara optimal maka persentase materi secara teori dialokascabe sebesar 20 persen dan praktek (proses 66 kerja) sebesar 80 persen. Adapun materi pokok dalam pembelajaran yaitu meliputi aspek teori tentang budidaya tanaman cabe.

\section{Implementasi Teknologi dan Proses Produksi}

Dalam rangka penyelesaian masalah spesifik usaha mitra yang mencakup beberapa kegiatan yaitu menghasilkan cabe maka nantinya tim pelaksana $\mathrm{I}_{\mathrm{b}} \mathrm{M}$ akan melakukan akivitas secara bersama-sama dengan mitra kelompok. Dalam kegiatan ini tim pelaksana $\mathrm{I}_{\mathrm{b}} \mathrm{M}$ bersama dengan anggota mitra terjun langsung dalam berbagai aktivitas usaha budidaya tanaman cabe. Pada bagian ini warga belajar dituntun juga untuk mengolah lahan, memasang mulsa, penanaman, pemberian pupuk organik dan anorganik.

\section{Pemantapan Program Kerja dan Evaluasi}

Untuk memantau kemajuan proram kerja, dilakukan dengan cara mengevaluasi secara langsung aktivitas kerja setiap peserta didik sejak sosialisasi (pengenalan), sampai pada implementasi program dan proses produksi. Aspek yang dievaluasi mencakup respons, tindakan nyata melalui perilaku kerja setiap anggota kelompok tani serta penguasaan pengetahuan (teori dan praktek) dengan tahapan sebagai berikut.

\section{Evaluasi Awal Program}

Evaluasi awal program yang diarahkan pada kegiatan survei dalam rangka mengkaji potensi sumberdaya alam 
dan manusianya yang dilibatkan berdasarkan kriteria kelompok sasaran. Aspek evaluasi ditekankan pula menyangkut penguasaan materi dasar, kesiapan mental, dan animo serta motivasi orientasi dalam mengikuti kegiatan.

\section{Evaluasi Program Berjalan}

Proses evaluasi dalam tahapan ini bertujuan untuk mengkaji tingkat efektivitas pelaksanaan program dalam mencapai tujuan dan sasaran dengan cara melakukan pengamatan langsung proses pelaksanaan kegiatan, tingkat penguasaan materi maupun keterampilan dalam melaksanakan tahapan kegiatan IbM.

\section{Evaluasi Akhir Program}

Evaluasi akhir program diarahkan pada pengkajian terhadap efektivitas pelaksanaan program dalam mencapai tujuan dan sasaran yang telah ditetapkan, mencakup penguasaan pengetahuan, keterampilan dan produksi yang dapat dihasilkan baik secara kuantitas maupun kualitas.

\section{HASIL DAN PEMBAHASAN}

\section{Sosialisasi Program}

Sosialisasi program yang akan dilakukan di desa Batu kecamatan Likupang Selatan. Pada Gambar 1 menunjukkan penyampaian program kegiatan pengabdian kepada masyarakat oleh Ketua Lembaga Pengabdian Kepada Masyarakat Unima. Pada sosialisasi program ini dihadiri oleh perangkat desa Batu dan masyarakat desa Batu yang menjadi sasaran pelaksanaan program (Gambar 1 dan Gambar 2).

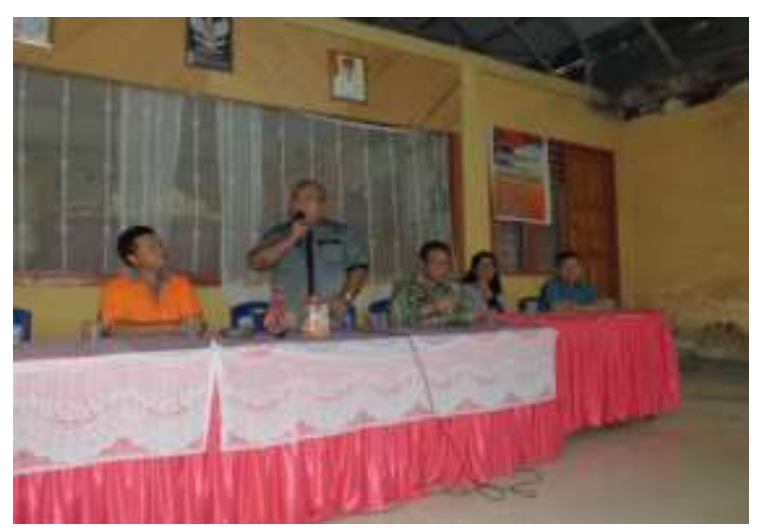

Gambar 1. Penjelasan PPM untuk sosialisasi program.

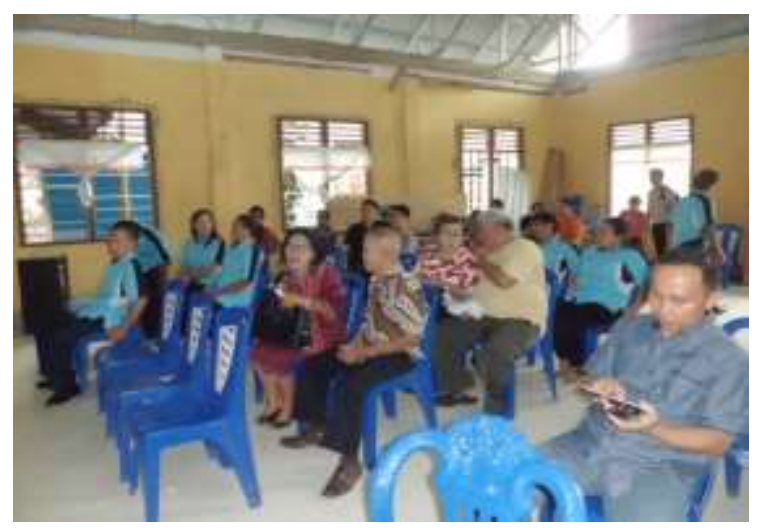

Gambar 2. Peserta sosialisasi program PPM.

Kegiatan ini dilaksanakan untuk mengawali seluruh rangkaian pelaksanaan program Sosialisasi merupakan salah satu tahapan penting dalam mengenalkan teknologi yang akan diterapkan pada kelompok usaha. Kegiatan tersebut menyangkut transformasi gambaran ilmu pengetahuan dan teknologi dalam upaya memecahkan masalah yang dihadapi oleh petani. Dalam kegiatan sosialisasi ini akan dijelaskan tentang teknologi yang akan disosialisasi yaitu budidaya tanaman cabe 
seperti persiapan lahan, penanaman, pemeliharaan, kemudian penanganan saat panen, pasca panen, serta pengolahan buah cabe menjadi produk olahan. Dalam sosialisasi dijelaskan pentingnya melakukan budidaya tanaman dengan memberikan mulsa berupa plastik. Penanganan pasca panen merupakan aspek yang perlu mendapat perhatian sehingga penjelasan tentang hal ini sangat diperlukan.

\section{Pelaksanaan Kegiatan}

Pelaksanaan meliputi perkecambahan benih (Gambar 3), dilanjutkan dengan pemindahan bibit cabai yang sudah berumur 1 minggu setelah perkecambahan. Pada Gambar 5 menunjukkan penjelasan pengendalian hama tungau dengan pengendalian secara kimia menggunakan akarisida dikombinasikan dengan insektisida. Tungau menyerang daun muda, permukaan daun yang terserang menjadi berwarna cokelat mengkilap (Syukur et al. 2017).

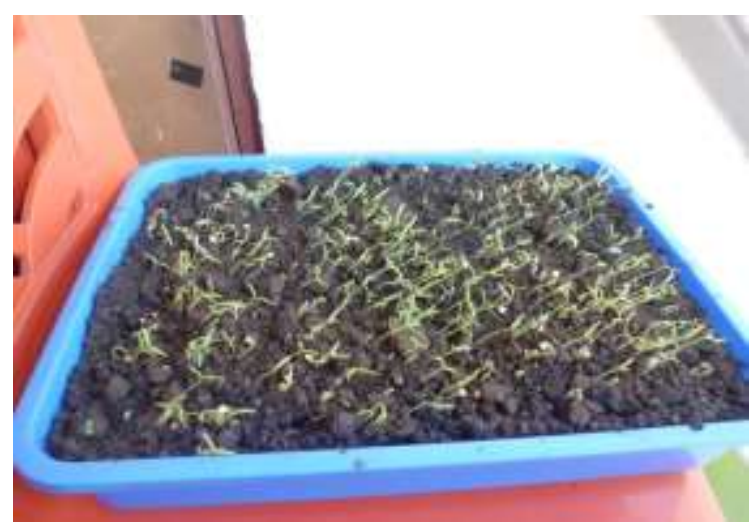

Gambar 3. Persiapan pembibitan.

Selain pembibitan mengunakan polibag hitam yang kecil, dapat memakai gelas bekas minuman (Gambar 6). 68
Tanaman cabe yang tumbuh pada gelas minuman terlihat mengalami masalah pertumbuhan yang ditunjukkan dengan lambatnya pertumbuhan. Petani mitra menyadari bahwa tanaman cabai yang dikecambahkan pada gelas bekas minuman akan mengalami hambatan dalam pertumbuhan.

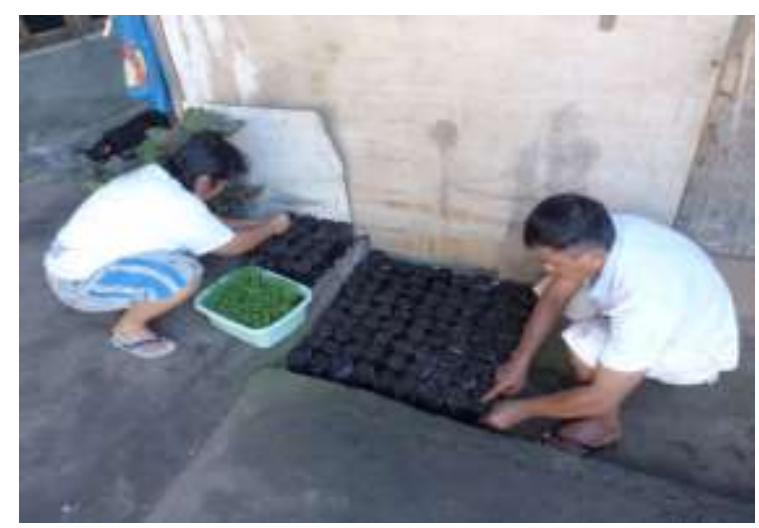

Gambar 4. Pemindahan bibit cabe di polibag.

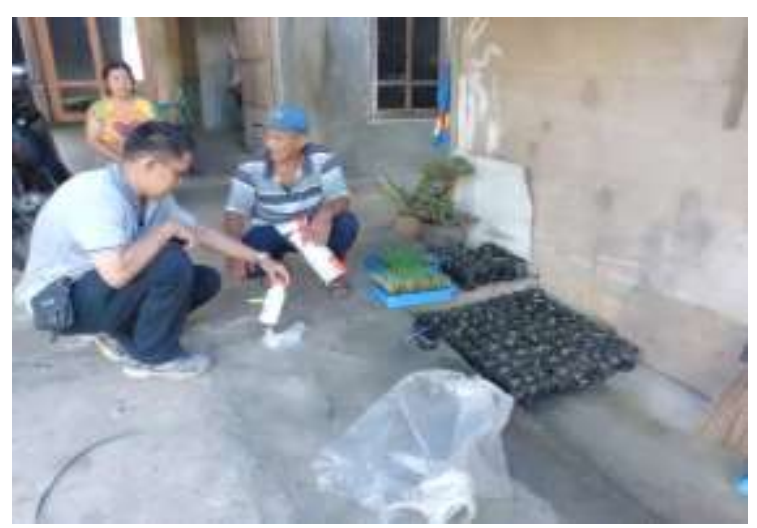

Gambar 5. Pemberian akarisida dan insektisida untuk pengendalian hama tungau.

Penanaman cabai dilakukan pada lahan tanpa menggunakan mulsa atau tanpa lapisan penutup tanah (Gambar 7) dan lahan yang menggunakan mulsa plastik (Gambar 8). Petani mitra sudah terbiasa melakukan praktik budidaya tanaman cabai tanpa mulsa plastik, sehingga pada 
melakukan budidaya cabai menggunakan mulsa plastik masih belum sesuai dengan praktik yang benar. Terlihat bedengan yang tidak tebal, lubang yang sangat besar, dan tidak adanya patok yang akan digunakan untuk penahan tanaman.

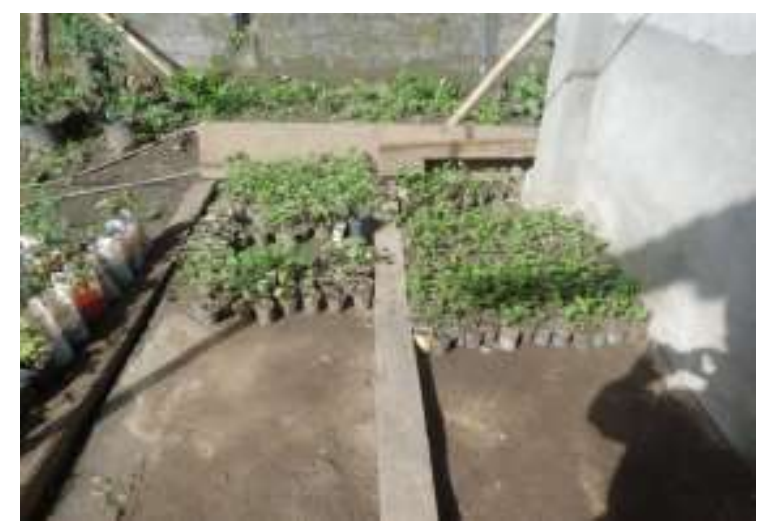

Gambar 6. Pembibitan cabe pada gelas bekas minuman yang dilakukan di halaman rumah.

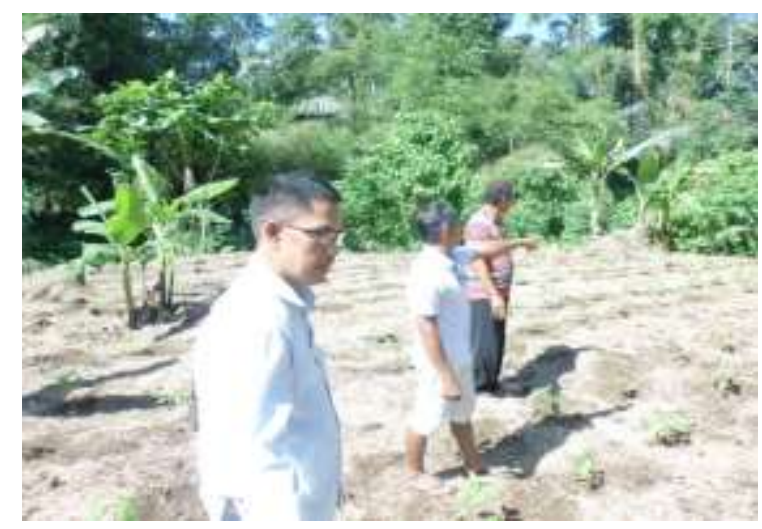

Gambar 7. Penanaman cabe tanpa menggunakan mulsa plastik.

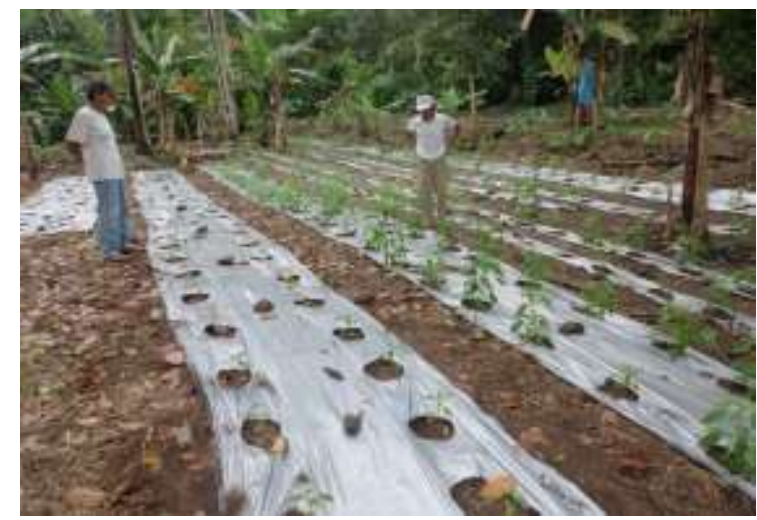

Gambar 8. Penanaman cabe pada mulsa plastik.
Tanaman cabe yang tidak menggunakan mulsa plastik memperlihatkan variasi pertumbuhan. Pada Gambar 9 dan 10, tanaman yang berumur 6 minggu setelah tanam terdapat tanaman cabai yang vegetatif yang baik dibanding tanaman cabai yang lain. Pertumbuhan vegetatif di antaranya tinggi tanaman yang tidak seragam, terdapat tanaman cabai yang lebih tinggi dari tanaman cabai yang lain. Variasi pertumbuhan ini disebabkan oleh faktor lingkungan yang tidak seragam seperti kelembaban tanah dan temperatur tanah.

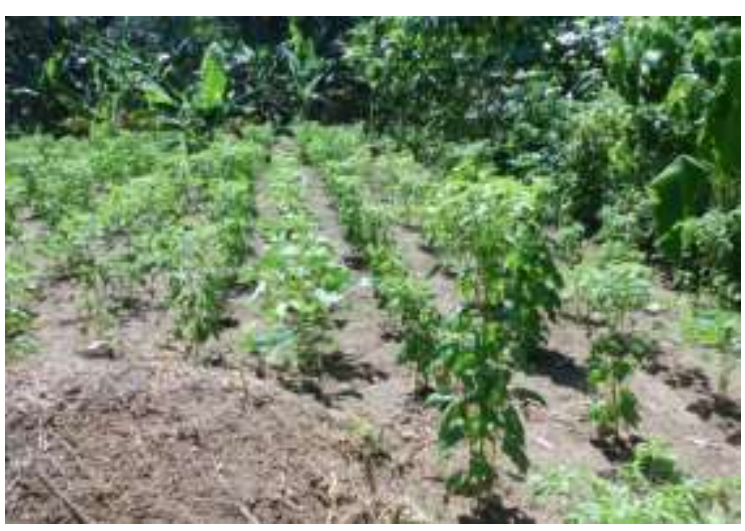

Gambar 9. Tanaman cabe yang berumur 6 minggu setelah tanam.

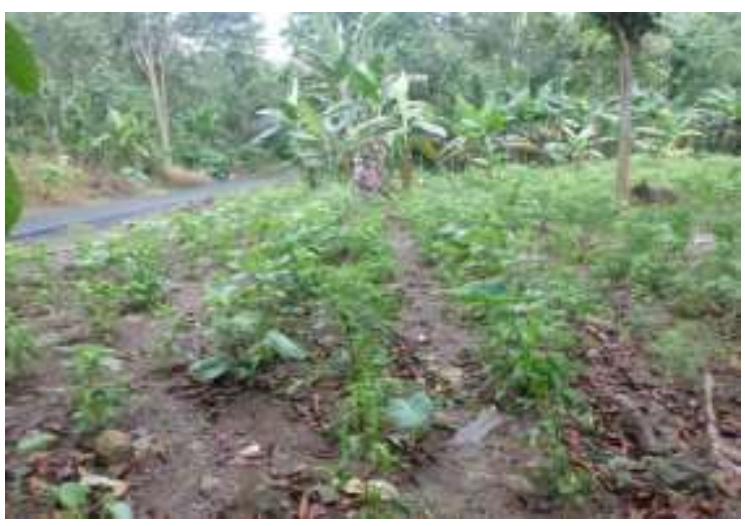

Gambar 10. Perkembangan cabe tanpa mulsa plastik umur 8 minggu setelah tanam.

Gambar 11 menunjukkan tanaman sudah membentuk bunga pada umur 4 
minggu setelah tanam. Beberapa keuntungan menggunakan mulsa yaitu temperatur dan kelembaban tanah relatif stabil, menghindari hilang unsur hara oleh guyuran air hujan dan penguapan air (Piay et al. 2010).

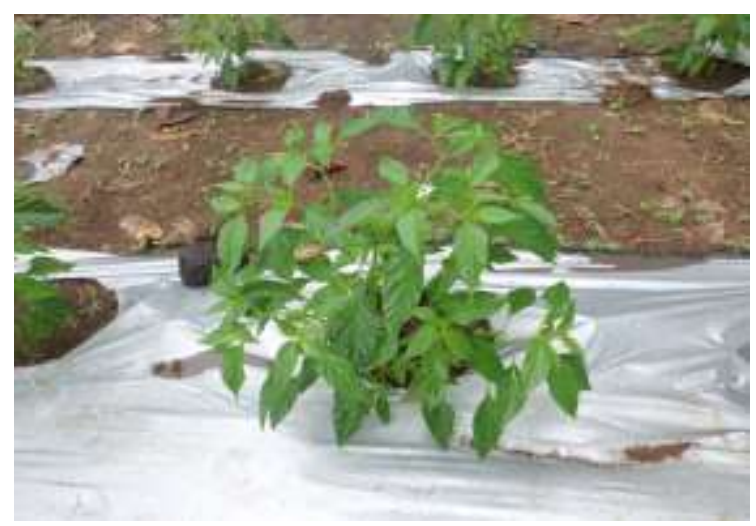

Gambar 11. Tanaman cabe keriting pada mulsa plastik berumur 4 minggu setelah tanam.

\section{KESIMPULAN}

1. Sosialisasi program pada kelompok tani di desa Batu Likupang Selatan dapat berjalan dengan baik.

2. Pemahaman yang meningkat dari petani mitra dalam budidaya tanaman cabai berupa praktik penanaman, pemeliharaan, dan pengendalian hama.

\section{KEPUSTAKAAN}

Piay SS, Tyasdjaja A, Ermawati Y, Hantoro FRP. 2010. Budidaya dan Pascapanen Cabai Merah (Capsicum annuum L.). Ungaran: Badan Penelitian dan Pengembangan Pertanian, BPTP Jawa Tengah.

Syukur M, Yunianti R, Dermawan R. 2017. Budidaya Cabai, Panen Setiap Hari. Jakarta: Penebar Swadaya. 